\title{
HYPOTHYROIDISM AND NEPHROTIC SYNDROME- A RARE ASSOCIATION
}

\author{
MD. JULHASH UDDIN ${ }^{1}$, KAZI MONJURUL ALAM ${ }^{2}$, FAZLE RABBI MOHAMMED ${ }^{3}$, MD. BILLAL ALAM ${ }^{4}$
}

\section{Introduction:}

Hypothyroidism may coexist with different renal pathologies. ${ }^{1}$ Several cases of glomerular diseases have been associated with thyroid diseases of which the most frequent lesion described is membranous glomerulopathy, presented as a nephrotic syndrome. ${ }^{2}$ Although pseudohypothyroidism is well-known in nephrotic pathophysiology, actual hypothyroidism are uncommon. ${ }^{3}$ We report here an unusual association of hypothyroidism due to Hashimoto's disease with nephrotic syndrome due to membranoproliferative glumerulonephritis which were revealed by hormone $\&$ antibody assay and renal biopsy respectively.

\section{Case report:}

A 61 year old female from Gazipur, presented to Tairunnessa Memorial Medical College \& Hospital with the complaints of generalized swelling of the body and fatigue for months. The swelling started at the legs and then gradually involved the whole body over the time period.

At presentation, the patient weighed $65 \mathrm{~kg}$ and measured $160 \mathrm{~cm}$ in height. On physical examination, there was mild periorbital swelling and peripheral edema with pulse rate -60 beats/minute, blood pressure-150/90 mm of Hg. But there was no palpable goitre, raised jugular venous pressure or stigmata of chronic liver disease on general examination. Abdominal examination revealed ascites and there was also slow releasing ankle jerks on nervous system examination. Dipstick urine testing demonstrated 3+ protein, suggesting the presence of nephrotic range proteinuria. Subsequent 24-hour urine collections revealed up to $9.3 \mathrm{~g}$ of protein in 24 hours along with a parallel decrease in serum albumin $27 \mathrm{~g} / \mathrm{l}$ (normal range $35-50 \mathrm{~g} / \mathrm{l})$. A marked mixed dyslipidaemia (cholesterol $7.1 \mathrm{mmol} / \mathrm{l}$, triglycerides $4.4 \mathrm{mmol} / \mathrm{l}$ ) was present in keeping with the nephrotic syndrome. Thyroid function tests showed a low free $\mathrm{T}_{4}$ concentration $(0.7 \mathrm{pmol} / \mathrm{l})$ with a TSH value above the normal range (10.11 mU/l). There was high titer of both antimicrosomal antibody and antithyroid peroxidase antibody indicating Hashimoto's disease. A renal biopsy was then performed and histology revealed membranoproliferative glumerulonephritis. (Fig.-1)

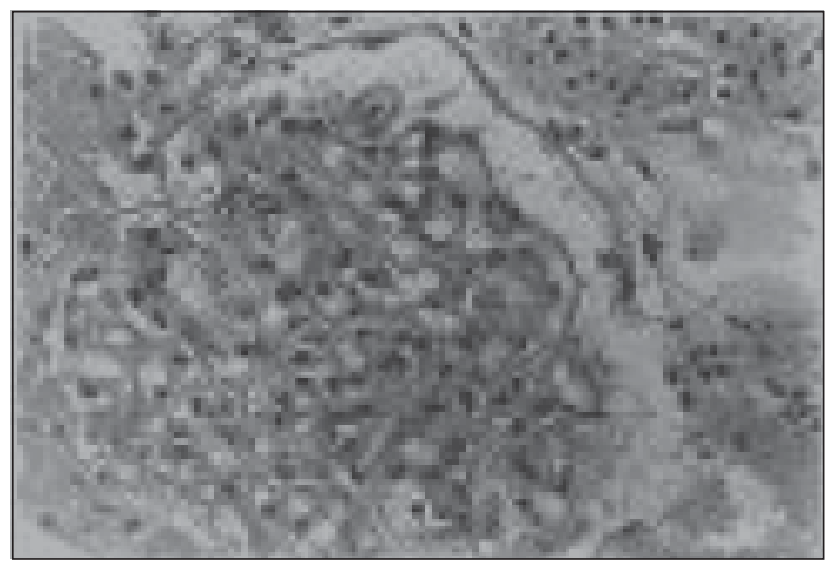

Fig.-1: Histopathological slide of membranoproliferative glumerulonephritis.

The patient was treated with a series of medical treatments including high dose prednisolone $(65 \mathrm{mg} /$ day), thyroxine, diuretics and ACEi therapy. Subsequently, urinary protein excretion and thyroid function tests remained stable on this regime with normalization of swelling of the body. The mixed dyslipidaemia was successfully controlled using statin therapy.

\section{Discussion:}

Nephrotic syndrome presenting with anasarca, massive proteinuria, low serum albumin and dyslipidaemia is a common phenomenon in Bangladesh. Diagnosis is suspected in patients with edema and proteinuria on urinalysis and confirmed by $24-\mathrm{h}$ measurement of urinary protein. A finding of $3 \mathrm{~g}$ protein in a 24 -h urine collection is diagnostic. The cause may be suggested by history but when the

1. Professor of Medicine, Shahabuddin Medical College \& Hospital.

2. FCPS (Medicine) Course Student, Department of Medicine, BSMMU.

3. Post Graduate Trainee, Department of Medicine, Dhaka Medical College \& Hospital.

4. Associate Professor, Department of Medicine, Dhaka Medical College, Dhaka

Correspondence : Dr. Md.Julhash Uddin, Professor of Medicine, Shahabuddin Medical College \& Hospital. 
cause is unclear, serological testing and renal biopsy are indicated. Although in nephrotic syndrome excessive thyroxine-binding protein and thyroxine urinary loss can generate low rate of free thyroxine and elevated $\mathrm{TSH}^{4}$ or rising thyroid stimulating hormone (TSH) levels in patients being treated for primary hypothyroidism by increasing urinary thyroid hormone loss ${ }^{5}$ Also congenital hypothyroidism detected on routine neonatal screening in an infant with congenital nephrosis of Finnish type ${ }^{6}$ are reported. But association of membranoproliferative glumerulonephritis and autoimmune mediated hypothyroidism is a rare finding.

In 2008, in Japan a 63-year-old man was admitted to a hospital for evaluation of generalized edema. Coexistence of severe hypothyroidism and nephrotic syndrome was detected by laboratory examination. High titer of both antimicrosomal antibody and antithyroid peroxidase antibody indicated Hashimoto's disease. Renal biopsy showed minimal change glomerular abnormality, but no finding of membranous nephropathy. This report is a rare case of autoimmune thyroid disease complicated with minimal change nephrotic syndrome. ${ }^{3}$ In Turkey in 2002, a case was reported with hypothyroidism and associated membranoproliferative glumerulonephritis. ${ }^{1}$
We, therefore, suggest a urinalysis for proteinuria, keeping in mind the nephrotic syndrome, whenever a patient present with hypothyroidism.

\section{References:}

1. Paydas S, Gokel Y. Different renal pathologies associated with hypothyroidism.Ren Fail. 2002;24:595-600.

2. Valentín M, Bueno B, Gutiérrez E, Martínez A, et al.Membranoproliferative glomerulonephritis associated with autoimmune thyroiditis. Nefrologia 2004;24:43-8.

3. Iwazu Y, Nemoto J, Okuda K,et al. A case of minimal change nephrotic syndrome with acute renal failure complicating Hashimotoâs disease.Clin Nephrol. 2008;69:47-52.

4. Trouillier S, Delèvaux I, Rancé N, et al. Increasing thyroxine requirements in primary hypothyroidism: don't forget the urinalysis!J Postgrad Med 2006;52:201-3.

6. Trimarchi F, Gemelli M , Benvenga S, et al.Transient congenital hypothyroidism in an infant with congenital nephrosis of finnish type. Acta Paediatrica 2008;72 : 145 - 147. 